\title{
Altered $m R$ NA expression of genes related to nerve cell activity in the fracture callus of older rats: A randomized, controlled, microarray study
}

\author{
Martha H Meyer, Wiguins Etienne and Ralph A Meyer Jr*
}

Address: Orthopaedic Research Laboratory, Department of Orthopaedic Surgery, Carolinas Medical Center, P.O. Box 32861, Charlotte, NC 282322861 USA

Email: Martha H Meyer - mmeyer@carolinas.org; Wiguins Etienne - wiguins.etienne@carolinas.org; Ralph A Meyer* - rmeyer@carolinas.org

* Corresponding author

Published: 03 August 2004

BMC Musculoskeletal Disorders 2004, 5:24 doi:10.1 I86/147/-2474-5-24

This article is available from: http://www.biomedcentral.com/I47/-2474/5/24

(C) 2004 Meyer et al; licensee BioMed Central Ltd.

This is an open-access article distributed under the terms of the Creative Commons Attribution License (http://creativecommons.org/licenses/by/2.0), which permits unrestricted use, distribution, and reproduction in any medium, provided the original work is properly cited.
Received: 25 March 2004

Accepted: 03 August 2004

\begin{abstract}
Background: The time required for radiographic union following femoral fracture increases with age in both humans and rats for unknown reasons. Since abnormalities in fracture innervation will slow skeletal healing, we explored whether abnormal mRNA expression of genes related to nerve cell activity in the older rats was associated with the slowing of skeletal repair.

Methods: Simple, transverse, mid-shaft, femoral fractures with intramedullary rod fixation were induced in anaesthetized female Sprague-Dawley rats at 6, 26, and 52 weeks of age. At 0, 0.4, I, 2, 4 , and 6 weeks after fracture, a bony segment, one-third the length of the femur, centered on the fracture site, including the external callus, cortical bone, and marrow elements, was harvested. cRNA was prepared and hybridized to 54 Affymetrix U34A microarrays (3/age/time point).

Results: The mRNA levels of 62 genes related to neural function were affected by fracture. Of the total, 38 genes were altered by fracture to a similar extent at the three ages. In contrast, eight neural genes showed prolonged down-regulation in the older rats compared to the more rapid return to pre-fracture levels in younger rats. Seven genes were up-regulated by fracture more in the younger rats than in the older rats, while nine genes were up-regulated more in the older rats than in the younger.
\end{abstract}

Conclusions: mRNA of 24 nerve-related genes responded differently to fracture in older rats compared to young rats. This differential expression may reflect altered cell function at the fracture site that may be causally related to the slowing of fracture healing with age or may be an effect of the delayed healing.

\section{Background}

Bone formation to bridge the fracture gap following skeletal fracture slows with age in both humans [1-6] and rats [7-9]. While young, 6-week-old rats reach radiographic union by 4 weeks after femoral fracture, adult, 26-weekold rats require 10 weeks, and older, 52-week-old rats need in excess of 6 months [7]. Despite this increased time to radiographic union with age, there was no increase in the time of expression of Indian hedgehog or any of the bone morphogenetic proteins in the fracture callus for adult rats [10] or for older rats $[11,12]$. Radiographic union for adult and older rats occurred well after the time 
of expression of these skeletally active cytokines [10,11]. Except for markers of osteoblast activity and bone matrix formation, few genes remain up-regulated during the time period when bone forms to bridge the fracture gap [10$12]$.

These earlier studies done with RT-PCR revealed a paucity of data for genes differentially expressed by age. We had hypothesized that bone formation to bridge the fracture gap would be under a negative-feedback control system. Thus, the genes which stimulate bone formation should be up-regulated in adult or older rats to attempt to accelerate their slower progression of bony healing. This was not observed in adult $[10]$ or older $[11,12]$ rats. Either bone formation to bridge the fracture gap is not subject to negative-feedback control, or the genes up-regulated to control this bone formation are not those normally thought of as being involved in skeletal homeostasis. This suggested the need for a wider search for genes active during the fracture reparative process.

In this project, mRNA gene expression was measured by DNA microarray technology at various time points after fracture for young, adult, and older rats. The goal was to identify genes whose expression following fracture was altered by age. Such genes may either show reduced expression, if the age-related slowing of healing is caused by inadequate expression levels, or they may show enhanced expression, in an attempt to stimulate some poorly responding pathway. Among the genes which were differentially expressed at the fracture site with age were genes related to nerve cell activity.

In this study, we explored whether abnormal mRNA expression of genes related to nerve cell activity was associated with the slowing of skeletal repair in older rats. Abnormalities in the innervation of the fracture site will slow skeletal healing clinically [13-15] and experimentally [16-18].

\section{Methods \\ Rats}

Intact female Sprague-Dawley rats (Harlan Sprague-Dawley, Inc., Indianapolis, IN) were purchased at one or six months of age and housed in our vivarium in pairs until they were the proper age for experimentation. The rats were fed Teklad Rodent Diet [W] (\#8604, Harlan Teklad, Madison, WI) and tap water ad libitum. The work was done in an AAALAC-accredited vivarium under protocols approved by our Institutional Animal Care and Use Committee.

\section{Surgery}

Intact female Sprague-Dawley rats at 6 (young), 26 (adult) or 52 (older) weeks of age, weighing $154 \pm 11 \mathrm{~g}$ (mean \pm
SD), $281 \pm 25 \mathrm{~g}$, and $330 \pm 30 \mathrm{~g}$ respectively, were anaesthetized with an intraperitoneal injection of ketamine and xylazine ( $30 \mathrm{mg}$ and $5 \mathrm{mg} / \mathrm{kg}$ body weight respectively) as described earlier $[7,11]$. The left knee was shaved, scrubbed with Betadine Solution (Purdue Frederick, Stamford, CT), and draped with sterile sheets. A medial incision was made at the knee, the patella was deflected laterally and a $1.0 \mathrm{~mm}$ hole was drilled into the intercondylar notch. An intramedullary rod $(1.0 \mathrm{~mm}$ diameter, stainless steel, type 304V, O-SWGX-400, Small Parts, Miami Lakes, FL) was placed retrograde into the left femur [11]. The incision was closed with wound clips. A closed simple transverse mid-diaphyseal femoral fracture was induced with a Bonnarens and Einhorn device [19]. Randomly selected rats from among those scheduled for surgery were used for 0 time no-fracture sham controls. Rats were euthanized at $0,0.4,1,2,4$, and 6 weeks after fracture for a total of 6 time points at each of the 3 ages. Six rats per time point per age group were selected for microarray analysis (2 rats/array). Radiographs were made at fracture, at 1 week after fracture, and at euthanasia. The femora were rapidly harvested, and one third of the femoral length, centered on the fracture site, was collected. This contained the fracture callus with associated cortical bone and marrow and was frozen in liquid nitrogen and stored at $-75 \mathrm{C}$.

\section{RNA Sample Preparation and Microarray Processing}

Samples were prepared as described in the Affymetrix GeneChip Expression Analysis Technical Manual (copyright 2001, Affymetrix, Inc., Santa Clara, CA, Rev. 1, Part number 701021, http://www.affymetrix.com). The sample preparation is described here in brief. Total RNA was extracted from the tissue by TRIzol (Invitrogen Life Technologies, Carlsbad, CA) with disruption of the tissue in a Brinkman Polytron homogenizer. RNA from two rats of the same age and time point was pooled for each microarray sample. Samples with $30 \mu \mathrm{g}$ RNA were purified on RNeasy columns by Qiagen (Valencia, CA, P/N 74104) and then converted to double-stranded cDNA with a Superscript Double Stranded cDNA Synthesis Kit (Invitrogen Life Technologies, P/N 11917-010). The cDNA was then expressed as biotin-labeled cRNA by in vitro transcription (IVT) with the Enzo RNA Transcript Labeling Kit (Affymetrix, P/N 900182). Each sample was spiked with bioB, bioC, bioD, and cre (Affymetrix $\mathrm{P} / \mathrm{N}$ 900299). The biotin-labeled cRNA was fragmented non-enzymatically. The fragmented cRNA was hybridized to 54 Rat U34A microarrays (Affymetrix P/N 900249) in the Affymetrix hybridization buffer for 16 hours at $45 \mathrm{C}$. The hybridized arrays were washed and stained in the Affymetrix Fluidics Station 400 to attach fluorescent labels to the biotin, followed by biotin-labeled antibody, and then a second staining with fluorescent labeling of the biotin. Each array was scanned twice by the Agilent GeneArray Scanner 
G2500A (Agilent Technologies, Palo Alto, CA). Three arrays from three independent samples (six rats) were done for each age at each time point.

\section{Data Analysis}

The Rat U34A GeneChip Microarray has probe sets for over 8,700 rat genes. Most probe sets have 20 different probes for the same gene on each array with 20 additional mismatch controls. The data were analyzed with Affymetrix Microarray Suite 5.0 and Affymetrix Data Mining Tool 3.0 software. Microarray Suite was used to scale the mRNA expression (signal value) of all genes to an average of 500 for each array. For each gene, the software reported a signal value and a Present/Marginal/Absent call. This latter algorithm was a statistical comparison of the variation among the several probe sets for each gene compared to the noise level and gave a call for each gene as Present, Marginal, or Absent. The program then compared the signal value of each gene in the fractured samples against the signal value of the same gene in the unfractured control sample. The difference between the two signal levels, relative to the variability between the multiple probes for each gene, yielded a probability of change due to chance alone. Genes with p less than 0.005 were judged significantly different from the same gene in the unfractured sample. This more conservative $\mathrm{p}$ value was employed to minimize false positive responses.

The Data Mining Tool was used for cluster analysis with the Self Organizing Map (SOM) algorithm. The data were clustered on the signal values between 20 and 20,000 with the maximum/minimum ratio of at least 3.0 and the maximum - minimum difference of at least 100 . One hundred clusters were specified.

Nerve-related genes were identified by searches for nerverelated names in the gene descriptions of each gene on the microarray. This association was confirmed by a review of the information for that gene in the NetAffx web site http:/ /www.affymetrix.com and in the PubMed database http:/ /www.ncbi.nlm.nih.gov/entrez/query.fcgi. GenBank accession numbers and names are shown for each gene. Each graph shows the average \pm SEM of the three microarrays that were done for each time point for each age. Significant changes in gene expression were demonstrated by $\mathrm{t}$ test and linear regression [20].

This report conforms to the MIAME standards of MGED http://www.mged.org. A copy of the full microarray data set has been deposited in the NCBI Gene Expression Omnibus http://www.ncbi.nlm.nih.gov/geo/ as series GSE594.

\section{Results \\ Radiology}

In all young rats, bone bridged the fracture gap by four weeks after surgery. By six weeks after fracture, remodeling was beginning to obscure the fracture site (Fig. 1). In contrast, bone bridging in the adult rats progressed more slowly. The adult rats did have a vigorous periosteal reaction at the site of the fracture and were approaching radiographic union by six weeks after surgery (Fig. 1). In the older, one-year-old rats, bridging of the fracture gap by bone progressed the slowest. They had a minimal periosteal reaction at six weeks after surgery (Fig. 1).

\section{General results}

On each array, on average, 5,200 genes were scored as absent, and 3,300 as present. Of these, 1,159 were significantly up-regulated and 928 were significantly down-regulated at two weeks after fracture in the adult rats of the first series (see Additional File 1). Up-regulated genes included cytokines and matrix genes for both cartilage and bone. Down-regulated genes included genes related to blood cell synthesis and mitochondrial function.

SOM clusters identified genes up- or down-regulated by fracture. Most genes affected by fracture followed the same time course at all three ages. These genes showed approximately the same peak expression level and regressed to baseline at about the same time point at all three ages. Among the genes affected by fracture were a number of genes associated with nerve cells. These were selected for more intense analysis.

\section{Similar responses at all three ages}

Up-regulated nerve-related genes are shown in Table 1. Two examples are shown in the upper two graphs in Figure 2. Both of these genes were significantly up-regulated from the 0 time control $(\mathrm{P}<0.001$ by t test for 9 samples ( 3 ages $\times 3$ replicates) of 0 time $v$ s. 0.4 week (Fig. 2, top graph) or $v s$. 0 time vs. 2 week (Fig. 2, middle graph)). Other nerve-related genes were down-regulated by fracture at all three ages (Table 2). These regained near normal activity by six weeks after fracture. An example is shown in the bottom graph of Figure 2. This gene (TAG-1) had a significant down-regulation after fracture $(\mathrm{P}<0.001$ by $\mathrm{t}$ test for 9 samples of 0 time vs. 0.4 week), followed by a significant increase at 6 weeks after fracture compared to 0.4 week after fracture $(\mathrm{P}<0.001$ by $\mathrm{t}$ test for 9 samples).

\section{Defects in the older rats}

SOM cluster analysis identified three types of defects in the older rats. In the first type, a number of genes were down-regulated by fracture at all three ages. However, while genes in the younger rats were returning to pre-fracture expression levels by six weeks after fracture, there was less recovery in the older rats. These genes are shown in 

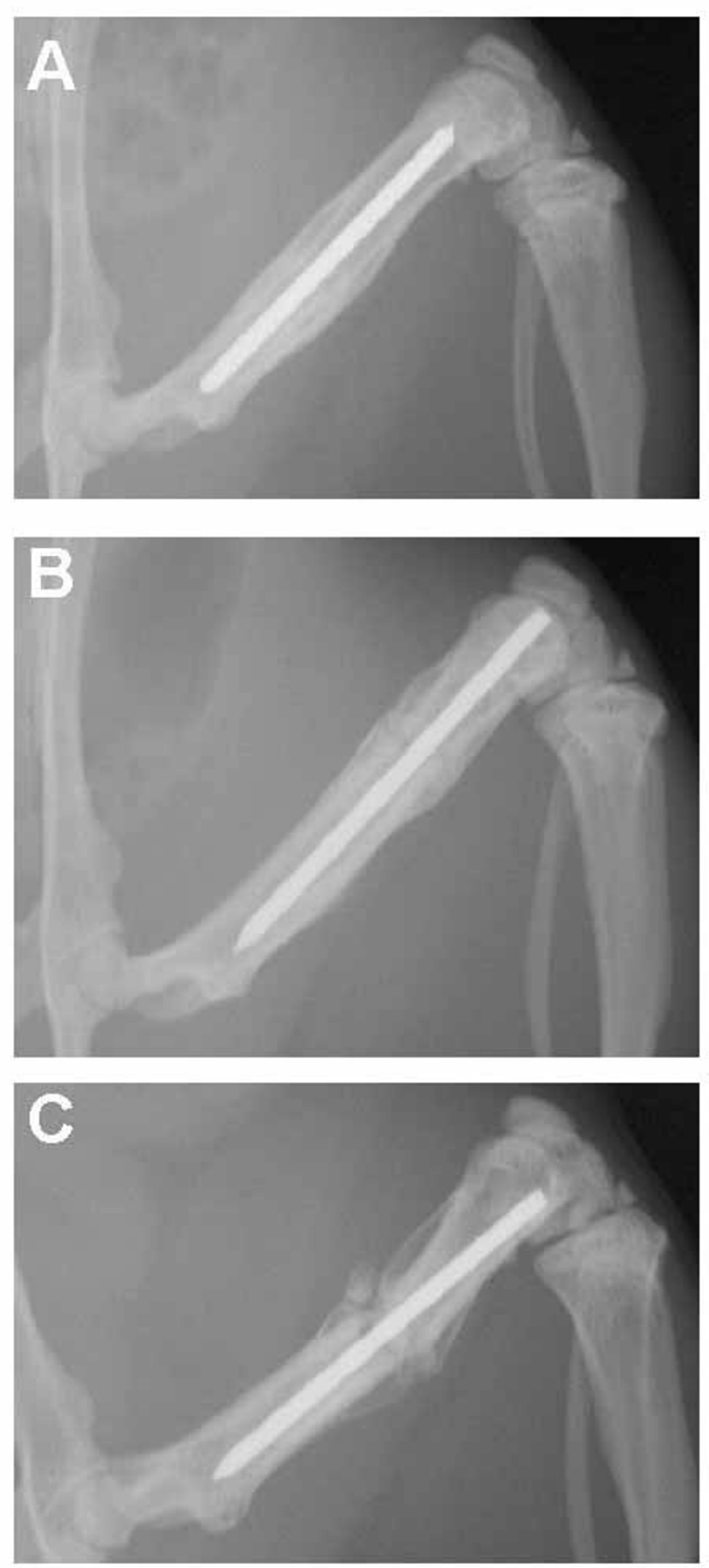

\section{Figure I}

Radiographs. Radiographs of the fractured left femora at 6 weeks after fracture in rats 6(A), 26(B), and 52(C) weeks old at fracture.
Table 3, and three examples of these genes are shown in Figure 3. All three of these genes had a significantly decreased mRNA expression levels at 1 week after fracture compared to 0 time control $(\mathrm{P}<0.001$ by t test for 9 samples $(3$ ages $\times 3$ replicates $)$ ). At 4 and 6 weeks after fracture, the young rats showed faster recovery in mRNA expression than did the older rats for the three genes in Fig. $3(\mathrm{P}<0.01$ by t tests for 4 and 6 week young $v$ s. 4 and 6 week old).

In the second type of defect, other genes were up-regulated by fracture, but the response was weaker in the older rats. These genes are shown in Table 4. Three examples are shown in Figure 4. The broad peaks of the genes in Figure 4 permitted the t test to demonstrate a significantly higher expression level in the young rats at 1 and 2 weeks after fracture in comparison to the same time points of older rats. These comparisons for the three genes in Figure 4 were significant at $\mathrm{P}<0.001$ (top graph, AF034963), $\mathrm{P}<$ 0.02 (middle graph, AB005541) and $\mathrm{P}<0.01$ (bottom graph, U09357) for 6 samples per age group (2 time points pooled for 3 replicates).

In the third type of defect, genes were also up-regulated by fracture. However, the response was stronger in the older rats than in the younger rats. These genes are shown in Table 5, and three examples are shown in Figure 5. The peak values for these three genes significantly increased with age by linear regression $(\mathrm{P}<0.001$ (top graph, AF030089), $\mathrm{P}=0.01$ (middle graph, M88469), and $\mathrm{P}<$ 0.001 (bottom graph, X89963) for 9 data points ( 3 ages $\times$ 3 replicates)).

\section{Present/Marginal/Absent calls}

For each gene for each array, the Microarray Suite software reported a statistical decision as to whether the mRNA was Present, Marginal, or Absent. We have reviewed these calls for the genes shown in Figures 2,3,4,5. For Figure 2, the Present/Marginal/Absent calls were: Fig. 2 Top: 53/1/0; Fig. 2 Middle: 39/2/13; and Fig. 2 Bottom: 0/0/54. For Figure 3, the calls were: Fig. 3 Top: 45/2/7; Fig. 3 Middle: $7 /$ 0/47; and Fig. 3 Bottom: 32/6/16. For Figure 4, the calls were: Fig. 4 Top: 0/0/54; Fig. 4 Middle: 0/0/54; and Fig. 4 Bottom: 51/0/3. For Figure 5, the calls were: Fig. 5 Top: 45/1/8; Fig. 5 Middle: 52/0/2; and Fig. 5 Bottom: 54/0/0.

\section{Discussion}

In this study, as in our earlier work [7,10-12], the time required to reach radiographic union after femoral fracture increased with age in the female rat. This slowing of fracture repair with age is associated with changes in the mRNA expression of specific genes within the healing fracture site [10-12]. To study this further, microarray technology was used to identify additional genes whose mRNA expression was affected by skeletal fracture. 
Table I: Nerve-related genes up-regulated by fracture at all three ages

\begin{tabular}{|c|c|c|}
\hline GenBank & Name & Reference \\
\hline \multicolumn{3}{|c|}{ Genes related to apoptosis } \\
\hline S67769 & Cardiac sodium/calcium exchanger (SIc8al) & [38] \\
\hline M82824 & Leucopus neurofibromatosis protein - type I (NFI) & [39] \\
\hline LII319 & Signal peptidase complex $18 \mathrm{kD}$ & {$[40]$} \\
\hline \multicolumn{3}{|c|}{ Genes up-regulated by injury } \\
\hline J03624 & Galanin (shown in Fig. 2) & [4I-43] \\
\hline E12625 & Rat novel protein expressed with nerve injury (sterol-C4-methyl oxidase-like) & [44] \\
\hline \multicolumn{3}{|c|}{ Genes related to nerve cell differentiation and growth } \\
\hline ZII558 & Glia maturation factor beta & {$[45-47]$} \\
\hline A03913 & Glia-derived neurite-promoting factor (serine (or cysteine) proteinase inhibitor, clade $\mathrm{E}$, member 2) & {$[48,49]$} \\
\hline E05646 & Hippocampal cholinergic neurostimulating peptide (phosphatidylethanolamine binding protein) & [50] \\
\hline$A B 0 I I 53 I$ & MEGF 5, slit homolog 3 & {$[51]$} \\
\hline AA924772 & Metallothionein 3 & {$[52,53]$} \\
\hline AF097593 & $\mathrm{N}$-cadherin, Testicular (cadherin 2) & {$[54,55]$} \\
\hline AF023087 & Nerve growth factor induced factor A (early growth response I) & {$[56,57]$} \\
\hline All 02795 & Pleiotrophin (heparin binding growth factor 8, Hbnf, neurite growth promoting factor I) (Fig. 2) & [58-60] \\
\hline LI9180 & Receptor-linked protein tyrosine phosphatase type D (protein tyrosine phosphatase, receptor type D) & [6I] \\
\hline AF0449I0 & Survival motor neuron & [62] \\
\hline U64689 & Synaptotagmin interacting protein zygin II (fasciculation and elongation protein zeta 2) & [63] \\
\hline \multicolumn{3}{|c|}{ 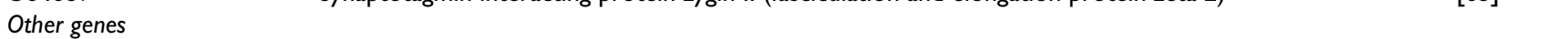 } \\
\hline L0728I & Carboxypeptidase E & {$[64,65]$} \\
\hline U03416 & Neuronal olfactomedin-related ER localized protein & [66] \\
\hline U67I40 & PSD-95/SAP 90 associated protein-4 (disks large-associated protein 4) & [67] \\
\hline M83680 & RABI4 (GTPase Rab I4) & {$[68]$} \\
\hline AF0I6247 & RTK40 homolog (tyro 10, discordin domain receptor family, member 2 ) & [69] \\
\hline X65454 & SC65 - Synaptonemal complex protein & {$[70]$} \\
\hline AJ006855 & Synaptojanin I & {$[7 I]$} \\
\hline M9660I & Taurine transporter (Slc6a6) & [72] \\
\hline U35245 & Vacuolar protein sorting homolog r-vps33b & [73] \\
\hline
\end{tabular}

Alternative names are shown in parentheses. References to physiological roles are shown to the right.

Table 2: Nerve-related genes down-regulated by fracture at all three ages

\begin{tabular}{|c|c|c|}
\hline Genbank & Name & Reference \\
\hline \multicolumn{3}{|c|}{ Genes associated with the growth cone of nerve fibers } \\
\hline M3I725 & Axonal glycoprotein TAG-I (Contactin 2) (shown in Fig. 2) & [74] \\
\hline S82649 & Neuronal activity-regulated pentraxin (Narp) & {$[75]$} \\
\hline$\times 59149$ & Neural cell adhesion molecule LI & {$[76-78]$} \\
\hline \multicolumn{3}{|c|}{ Genes associated with synaptic signaling pathways } \\
\hline L08496 & GABA-A receptor delta subunit & [79] \\
\hline S68944 & $\mathrm{Na}^{+} / \mathrm{Cl}-$-dependent neurotransmitter transporter & {$[80]$} \\
\hline S76742 & Neurotransmitter transporter rB2 la (X transporter protein 3 ) & [8I] \\
\hline U39549 & Synaptogyrin (synaptogyrin I) & [82] \\
\hline $\mathrm{D} 28512$ & Synaptotagmin III (synaptotagmin 3) & [83] \\
\hline AF007758 & Synuclein I (synuclein alpha) & [84] \\
\hline \multicolumn{3}{|l|}{ Other genes } \\
\hline AF08I557 & Glial cells missing protein homolog (Gcm I, glial cells missing homolog a) & [85] \\
\hline LI5305 & Glial-derived neurotrophic factor & [86] \\
\hline M24852 & Neuron-specific protein PEP-19 (Purkinje cell protein 4) & {$[87]$} \\
\hline DI752I & Protein kinase C-regulated chloride channel & [88] \\
\hline
\end{tabular}

Data presented as in Table I. 

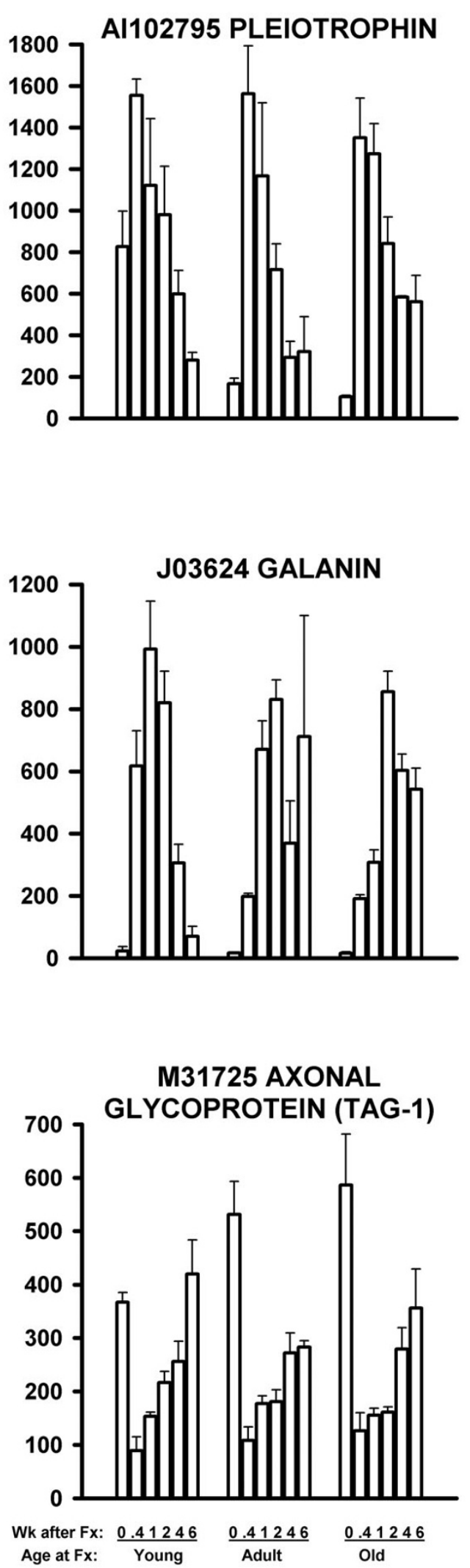

Figure 2
Figure 2

mRNA levels of three nerve-related genes affected by fracture in young, adult, and older rats. The first two genes were up-regulated at all three ages ( 0.4 week (top graph) and 2 weeks (middle graph) exceed 0 time control at $\mathrm{P}<0.00 \mathrm{I}$ ), while the third gene was down-regulated at all three ages ( 0.4 week significantly less than 0 time control at $P$ $<0.001$ ). Rats were 6, 26 and 52 weeks of age at fracture respectively. Samples were collected at the indicated times after fracture. The 0 time samples were no-fracture controls. Each bar is the mRNA expression level for the indicated gene for the average \pm SEM of three DNA microarrays in arbitrary units of fluorescence. mRNA from two rats of the same age and time after fracture were pooled for each array. Gene identifications are shown with their GenBank accession number. Axonal glycoprotein (TAG-I) is also known as contactin 2.

More than two-thirds of the detectable genes on the rat U34A microarray have a change in mRNA expression level following fracture [21]. Most of these genes were not known to participate in the healing process of bone before the advent of microarray technology $[21,22]$. This reflects changes in both the types of cells at the fracture site as well as changes in the activity of the existing cells. Among the cells affected by fracture are nerve fibers. Protein and mRNA of genes related to neuronal functioning are found in intact bone and in the fracture callus [23-29]. Since proper innervation of the fracture site is needed for fracture repair clinically [13-15] and experimentally [16$18]$, this led to the hypothesis that the age-related slowing of fracture repair may be related to the abnormal nerve cell activity at the fracture site.

To evaluate this hypothesis, nerve-related genes were studied from among the genes present on the Affymetrix Rat U34A microarray. Genes were identified for which the mRNA response to femoral fracture was changed in the older rats compared to the young rats. Three types of change with age were found:

1. The mRNA expression levels of the genes shown in Table 3 and Figure 3 were decreased by fracture. While gene expression in the young rats was approaching prefracture levels by six weeks after fracture, gene expression showed minimal return to normal in older rats. Genes in this category were all related to signaling molecules or to signal receptors (references shown in Table 3 ).

2. Other nerve-related genes had strong up-regulation after fracture in young rats but only mild up-regulation in older rats. These are shown in Table 4 and Figure 4. This partial loss of function with age was observed in genes associated with nerve cell differentiation or cell cycle or 
Table 3: Nerve-related genes with prolonged down-regulation after fracture in older rats

\begin{tabular}{lll}
\hline GenBank & Name & Reference \\
\hline L09119 & C kinase substrate calmodulin-binding protein (neurogranin) (shown in Fig. 3) & {$[89]$} \\
S77867 & G coupled protein receptor UHR-I (G protein coupled receptor 10) & {$[90]$} \\
AFI09405 & GABA-B receptor 2 (G protein-coupled receptor 5I) & {$[91]$} \\
U08290 & Neuronatin alpha (neuronatin) & {$[92]$} \\
MI5880 & Neuropeptide Y (shown in Fig. 3) & {$[93,94]$} \\
S56508 & Fatty acid coenzyme A ligase, long chain 6 & {$[95]$} \\
AF041083 & RoBo-I (Slcl Ial) (shown in Fig. 3) & {$[55,96,97]$} \\
X86789 & Sensory neuron synuclein (gamma-synuclein) & {$[98,99]$} \\
\hline
\end{tabular}

Data presented as in Table I. All genes are related to signals and signal receptors.

Table 4: Nerve-related genes with a greater up-regulation in younger rats

\begin{tabular}{|c|c|c|}
\hline GenBank & Name & Reference \\
\hline \multicolumn{3}{|c|}{ Genes related to nerve cell differentiation and the cell cycle } \\
\hline X86003 & Neuron-derived orphan receptor-2 & {$[100]$} \\
\hline AB005540 & PCTAIRE 2 & {$[101]$} \\
\hline AB00554I & PCTAIRE 3 (shown in Fig. 4) & {$[102]$} \\
\hline U09357 & Protein tyrosine phosphatase, receptor-type, Z polypeptide I (shown in Fig. 4) & {$[103]$} \\
\hline \multicolumn{3}{|c|}{ Genes related to the synapse and sensory perception } \\
\hline All 79632 & Proton gated cation channel DRASIC & {$[104]$} \\
\hline AF034863 & Synaptic scaffolding molecule (S-SCAM, activin receptor interacting protein I) (shown in Fig. 4) & {$[105,106]$} \\
\hline S56|4l & Sodium-dependent neurotransmitter transporter & {$[107]$} \\
\hline
\end{tabular}

Data presented as in Table I.

Table 5: Nerve-related genes with a greater up-regulation in older rats

\begin{tabular}{|c|c|c|}
\hline GenBank & Name & Reference \\
\hline \multicolumn{3}{|c|}{ Genes related to signals and signal transduction } \\
\hline X74832 & Acetylcholine receptor alpha subunit (cholinergic receptor, nicotinic, alpha polypeptide I) & {$[108]$} \\
\hline$M 16112$ & Brain type II calcium/calmodulin dependent protein kinase beta subunit & [109] \\
\hline \multicolumn{3}{|c|}{ Genes related to cell adhesion } \\
\hline M88469 & F-spondin (shown in Fig. 5) & {$[110]$} \\
\hline AF060879 & Neurocan (chondroitin sulfate proteoglycan 3) & {$[111,112]$} \\
\hline U16845 & Neurotrimin & {$[113]$} \\
\hline M96375 & Non-processed neurexin I-beta (neurexin I) & {$[114]$} \\
\hline X89963 & TSP-4 (thrombospondin-4) (shown in Fig. 5) & {$[115-117]$} \\
\hline \multicolumn{3}{|l|}{ Other genes } \\
\hline AF030089 & Activity and neurotransmitter-induced early gene 4 (ania-4) (shown in Fig. 5) & {$[118]$} \\
\hline D88250 & Serine protease (complement component I, s subcomponent) & {$[119]$} \\
\hline
\end{tabular}

Data presented as in Table I.

genes related to synaptic structure (references cited in Table 4).
3. A third set of genes was increased in mRNA expression by fracture, but the increase was greater in the older rats. These are shown in Table 5 and Figure 5. Many of these 

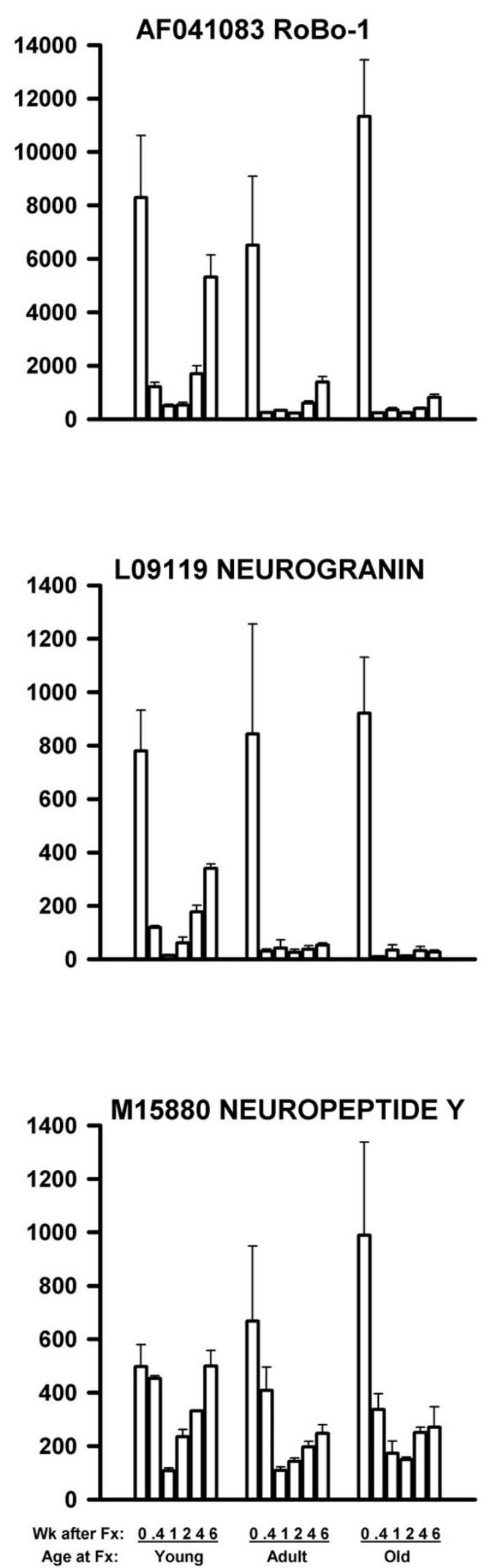

Figure 3
Figure 3

mRNA levels of three nerve-related genes with more prolonged down-regulated after fracture in the older rats. The I week values were significantly less than 0 time controls for all three graphs $(P<0.00 I)$. Note the failure of the mRNA activity to return to pre-fracture levels in the older rats ( 4 and 6 week values for young exceeded older rat values at $P<0.01$ ). The data are presented as in Figure 2.

genes were related to cell adhesion or to cell signal or signal transduction (references cited in Table 5).

All three classes of genes showed altered expression in the older rats compared to young rats. We hypothesize that bone fracture may physically disrupt nerve fibers in bone. A sub-population of these skeletal nerve fibers may regrow into the fracture site or regain function at a slower rate in older rats. This may account for the failure to recover from low mRNA values for the first group (prolonged down-regulation) or the failure to up-regulate mRNA expression adequately after fracture in the older rats in the second group (diminished up-regulation). Other genes in the third group with increased levels of mRNA after fracture in the older rats may represent attempts to stimulate nerve regrowth or other processes that are not responding. This may represent negative-feedback-induced up-regulation caused by effector cell resistance. Taken together, these changes in nerve cell function with age may contribute to the slowing of fracture repair in older rats. It must be pointed out that the associations noted here do not necessarily reflect cause and effect. It is also possible that the delayed re-innervation of the fracture site is an effect of the delayed healing in the older rats and not a cause of the delayed healing.

Experimental studies have been done to detect the role of innervation on fracture healing. Studies of sectioning the sciatic nerve in concert with tibial fracture have been reported to speed fracture healing [30-33]. However, sectioning both femoral and sciatic nerves inhibits fracture healing [18]. Aro et al. [16] have reported mechanoreceptors (Pacinian corpuscles) in the periostium of the rat fibula, which, if removed, lead to non-union [17]. Direct application of nerve growth factor to the fracture site increases healing in the rat rib [34].

In humans, abnormal bone healing is also associated with lack of nerve activity at the fracture site. Nagano et al. [13] have noted scaphoid nonunion in the wrists of patients with neuroarthropathy from a long-standing nerve palsy. Santavirta et al. [14] have found a lack of peripheral innervation at the fracture site of noninfected fractures with delayed union or nonunion of diaphyseal bones. Nord- 

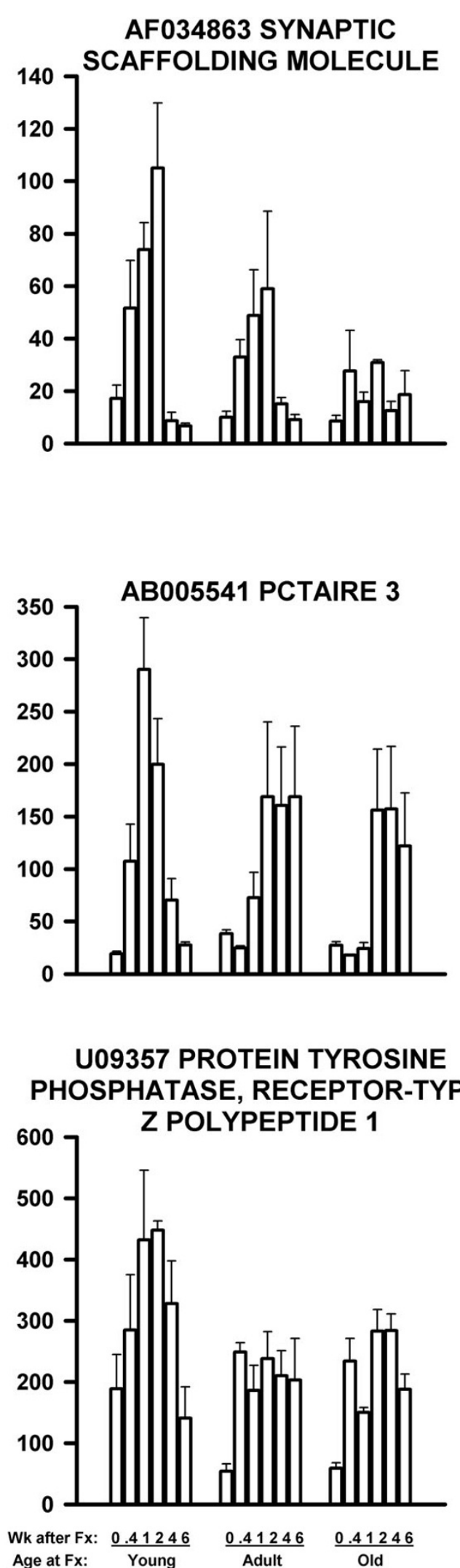

Figure 4
Figure 4

mRNA levels of three genes related to nerve function and up-regulated more in young rats than in older rats following femoral fracture. The decline with age was significant at $\mathrm{P}<0.00$ I (top graph), $\mathrm{P}<0.02$ (middle graph) and $P=0.01$ (bottom graph). The data are presented as in Figure 2.

strom et al. [15] have found a lack of stromal innervation associated with delayed union or pseudoarthrosis in spondylolysis.

Humans [1-6] show a slowing of fracture healing with increasing age as do rats [7-9]. The cause of the slowing of fracture healing with age is not well understood. The femora of young rats regain normal biomechanical properties by 4 weeks after fracture, while adults take 12 weeks, and older rats require in excess of 6 months [7]. This model presents an opportunity to elucidate novel genes important to this healing process. The slowing could reflect a loss of function as some processes essential for the rapid healing of fractures in young animals are inhibited with age. Alternatively, the slowing of skeletal repair with age may be caused by partial resistance of the healing process to stimulation in adult or older individuals. Such resistance should result in enhanced stimulation by regulatory systems to attempt to evoke a healing response. Both patterns were seen among the genes studied in this report. These genes are candidates for further study.

These changes with age are not limited to genes related to neuronal activity. We have also noted similar changes in genes related to mitochondrial activity [35]. It is likely that the age-related changes in fracture repair are caused by failure of several metabolic pathways. Methods, such as DNA microarrays, which sample many different biological pathways will be useful in defining these novel, multi-faceted defects.

The specificity of these changes is seen in the majority of the nerve-related genes for which the expression pattern following fracture was unaffected by age. These transcripts had similar increases or decreases following fracture in the young, adult, and older rats. These uniform responses suggest that most metabolic patterns were unaffected by age. Nerve-related genes similarly up-regulated by femoral fracture at all three ages were broadly related to differentiation and growth of nerve cells, to known up-regulation following nerve injury, or to association with apoptosis (references cited in Table 1). Some of these genes were slower to return to baseline values in older rats, such as galanin and TAG-1. In contrast, nerve-related genes similarly down-regulated by femoral fracture at all three 

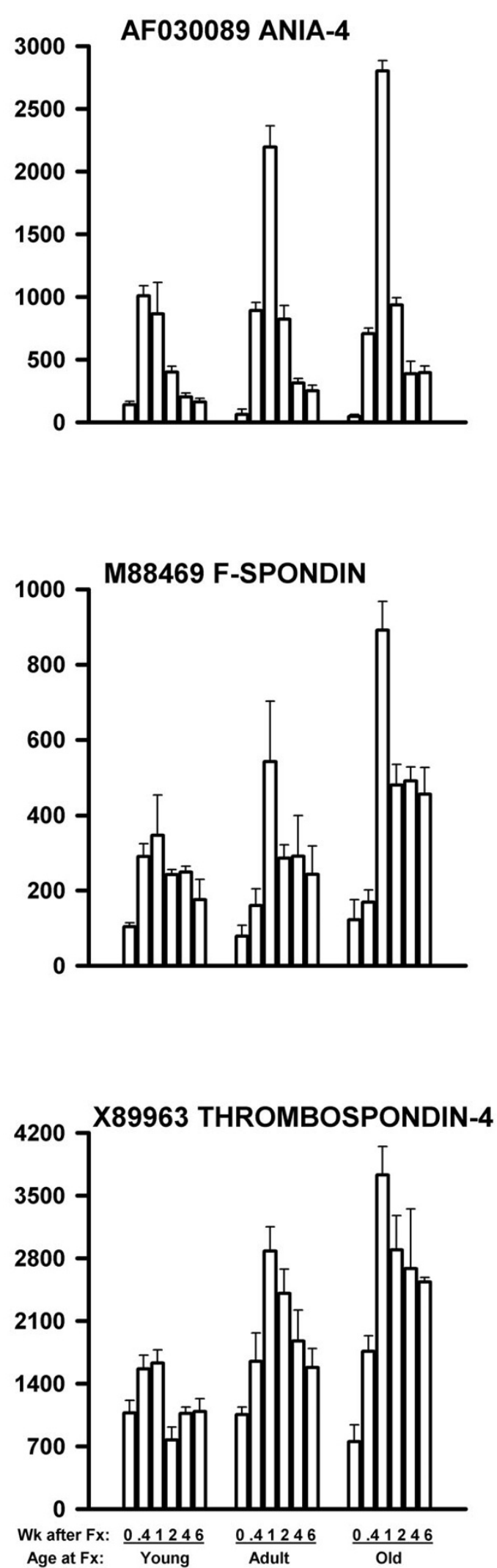

Figure 5
Figure 5

mRNA levels of three genes related to nerve function and up-regulated more in older rats than in younger rats following femoral fracture. The increase with age was significant at $\mathrm{P}<0.00 \mathrm{I}$ (top graph), $\mathrm{P}=0.0 \mathrm{I}$ (middle graph), and $\mathrm{P}<0.00$ I (bottom graph). The data are presented as in Figure 2.

ages were broadly related to the nerve growth cone or to synaptic signaling pathways (references cited in Table 2).

In this study gene expression was measured by quantification of the mRNA level for each gene with microarray technology. It must be kept in mind that there are other control systems which influence the protein synthetic rate and also protein degradation. Protein synthesis will be low in the absence of mRNA for that gene, but elevated mRNA levels are not a guarantee that protein levels will also be elevated for that gene. Changes noted at the mRNA level will need to be confirmed at the protein and structural levels. Assignment of the genes studied herein as nerve-related is made on the basis of currently available information. Other cell types in the fracture callus may also express these genes. Histological studies will permit the association of these genes with specific cell types within the fracture callus. These experiments are now in progress.

We have compared mRNA gene expression by microarray to that measured by reverse transcription - polymerase chain reaction (RT-PCR)[36]. Good correlation was found between the two methods if the transcripts were judged mostly present, the signal level did not approach the upper limit of the detector, and the probe sets or PCR primers were from the same region of the gene [36]. Some other genes, even though most samples were judged absent, also gave good correlation between the two methods. These latter genes were at the upper range of the absent calls and had good precision between samples [36]. The genes reported herein have the marked variation in mRNA levels that have been reported previously in fracture samples $[10,11]$ with large changes in expression after fracture which return to the prefracture levels as healing progresses. The finding here of moderate signal levels, good precision among the three samples for each time point at each age, and a strong response to fracture indicate the ability of this technology to report changes in mRNA levels for these genes.

\section{Conclusions}

In summary, most genes respond to bone fracture with altered mRNA gene expression, including genes related to neuronal functioning. However, a number of these genes 
responded to fracture differently in older rats than in young rats. Such differential expression with age may reflect altered cell functioning at the fracture site that may be related to the slowing of fracture healing in older rats.

\section{Competing interests}

\section{None declared.}

\section{Authors' contributions}

$\mathrm{MM}, \mathrm{WE}$, and RM participated in the surgery and the sample collection. MM and WE prepared and hybridized the samples and analyzed the data. RM prepared the manuscript. All authors read and approved the final manuscript.

\section{Additional material}

\section{Additional File 1}

Additional File 1. Response of adult rats at two weeks after fracture. This spreadsheet is a listing of all genes altered by fracture in the first adult rat sample at two weeks after fracture compared to the first adult no-fracture sample. The data are sorted on the probability value for the comparison of each gene between the two arrays. For each array, the signal (mRNA transcript level), detection (present, absent, or marginal) and detection pvalue are given. In addition, for the two-week sample, the change (increase, marginal increase, marginal decrease or decrease) and change p-value are given for the comparison of the two-week sample to the nofracture sample. These two arrays are archived in the GEO repository http://www.ncbi.nlm.nih.gov/geo/ as samples GSM9028 (no-fracture sample) and GSM9031 (2-week sample).

Click here for file

[http://www.biomedcentral.com/content/supplementary/14712474-5-24-S1.xls]

\section{Acknowledgements}

This study was supported in part by grants from the North Carolina Biotechnology Center and the Orthopaedic Trauma Association. We thank Drs. Scott Porter, James Fiechtl and Daniel Heiner for their surgical assistance. We thank Ms. Virginia Mooney, Mr. Michael Steuerwald, and Ms. Jessica Heath for their technical assistance and Ms. Carolyn Ayers for her secretarial assistance. A preliminary report of this study has appeared [37].

\section{References}

I. Bronk JT, Ilstrup D, Melton J, Bolander ME: Age and gender effect fracture repair in the humerus. Trans Orthop Res Soc 1997, 22:258 (Abstract).

2. Skak SV, Jensen TT: Femoral shaft fracture in $\mathbf{2 6 5}$ children. Lognormal correlation with age of speed of healing. Acta Orthop Scand 1988, 59:704-707.

3. Nieminen S, Nurmi M, Satokari K: Healing of femoral neck fractures; influence of fracture reduction and age. Ann Chir Gynaecol 1981, 70:26-31.

4. Nilsson BE, Edwards P: Age and fracture healing: A statistical analysis of 418 cases of tibial shaft fractures. Geriatrics 1969, 24: $112-117$

5. Hee HT, Wong HP, Low YP, Myers L: Predictors of outcome of floating knee injuries in adults: 89 patients followed for 2-I 2 years. Acta Orthop Scand 200I, 72:385-394.

6. Kawai T, Murakami S, Hiranuma H, Sakuda M: Radiographic changes during bone healing after mandibular fractures. $\mathrm{Br} J$ Oral Maxillofac Surg 1997, 35:312-318.
7. Meyer RA Jr, Tsahakis PJ, Martin DF, Banks DM, Harrow ME, Kiebzak GM: Age and ovariectomy impair both the normalization of mechanical properties and the accretion of mineral by the fracture callus in rats. J Orthop Res 200I, I 9:428-435.

8. Ekeland A, Engesæter LB, Langeland $N$ : Influence of age on mechanical properties of healing fractures and intact bones in rats. Acta Orthop Scand 1982, 53:527-534.

9. Bronk JT, Urabe K, Liang T, Bolander ME: The effect of age on fracture repair in a rat femur model. Trans Orthop Res Soc I996, 2 I :200 (Abstract).

10. Desai BJ, Meyer MH, Porter S, Kellam JF, Meyer RA Jr: The effect of age on gene expression in adult and juvenile rats following femoral fracture. J Orthop Trauma 2003, I 7:689-698.

II. Meyer RA Jr, Meyer MH, Tenholder M, Wondracek S, Wasserman R, Garges P: Gene expression in older rats with delayed union of femoral fractures. J Bone Joint Surg [Am] 2003, 85A: | 243-I 254.

12. Meyer RA Jr, Meyer MH, Phieffer LS, Banks DM: Delayed union of femoral fractures in older rats: Decreased gene expression. BMC Musculoskelet Disord 200I, 2:2.

13. Nagano J, Tada K, Masatomi T, Horibe S: Arthropathy of the wrist in leprosy-what changes are caused by long-standing peripheral nerve palsy? Arch Orthop Trauma Surg 1989, 108:210-217.

14. Santavirta S, Konttinen YT, Nordstrom D, Makela A, Sorsa T, Hukkanen M, Rokkanen P: Immunologic studies of nonunited fractures. Acta Orthop Scand 1992, 63:579-586.

15. Nordstrom D, Santavirta S, Seitsalo S, Hukkanen M, Polak JM, Nordsletten L, Konttinen YT: Symptomatic lumbar spondylolysis. Neuroimmunologic studies. Spine 1994, 19:2752-2758.

16. Aro $\mathrm{H}$, Eerola $\mathrm{E}$, Aho AJ: Osteolysis after rigid fixation. The possible role of periosteal neural mechanoreceptors in bone remodeling. Clin Orthop 1982, 166:292-300.

17. Aro H, Eerola E, Aho AJ: Development of nonunions in the rat fibula after removal of periosteal neural mechanoreceptors. Clin Orthop 1985, 199:292-299.

18. Madsen JE, Hukkanen M, Aune AK, Basran I, Moller JF, Polak JM, Nordsletten L: Fracture healing and callus innervation after peripheral nerve resection in rats. Clin Orthop 1998, $35 \mathrm{I}: 230-240$.

19. Bonnarens F, Einhorn TA: Production of a standard closed fracture in laboratory animal bone. J Orthop Res 1984, 2:97-I0I.

20. Zar JH: Biostatistical Analysis 2nd edition. Englewood Cliffs: PrenticeHall, Inc.; 1984.

21. Meyer RA Jr, Desai BR, Meyer MH: Age alters mRNA gene expression in the fracture callus of rats by microarray analysis. Trans Orthop Res Soc 2003, 28:489 (Abstract).

22. Hadjiargyrou M, Lombardo F, Zhao S, Ahrens W, Joo J, Ahn H, Jurman M, White DW, Rubin CT: Transcriptional profiling of bone regeneration. Insight into the molecular complexity of wound repair. J Biol Chem 2002, 277:30177-30182.

23. Dickson GClingen-Vance H: Neuropeptide immunoreactivity in repairing I.M. nailed rat femoral osteotomies. Program, International Society for Fracture Repair 2002:5 I (Abstract).

24. Grills BL, Schuijers JA: Immunohistochemical localization of nerve growth factor in fractured and unfractured rat bone. Acta Orthop Scand 1998, 69:415-419.

25. Hattorl A, Tsujimoto M, Hayashi K, Kohno M: Bone morphogenetic protein-2 is markedly synergistic with tumor necrosis factor in stimulating the production of nerve growth factor in fibroblasts. Biochem Mol Biol Int 1996, 38: I095-I IOI.

26. Rusanen M, Korkala O, Gronblad M, Partanen S, Nederstrom A: Evolution of substance $P$ immunofluorescent nerves in callus tissue during fracture healing. J Trauma I 987, I 2: I 340-I 343.

27. Hukkanen M, Konttinen YT, Santavirta S, Paavolainen P, Gu XH, Terenghi G, Polak JM: Rapid proliferation of calcitonin generelated peptide-immunoreactive nerves during healing of rat tibial fracture suggests neural involvement in bone growth and remodelling. Neuroscience 1993, 54:969-979.

28. Li J, Ahmad T, Spetea M, Ahmed M, Kreicbergs A: Bone reinnervation after fracture: a study in the rat. J Bone Miner Res 200I, 16:I505-I5I0.

29. Hukkanen M, Konttinen YT, Santavirta S, Nordsletten L, Madsen JE, Almaas R, Oestreicher AB, Rootwelt T, Polak JM: Effect of sciatic nerve section on neural ingrowth into the rat tibial fracture callus. Clin Orthop 1995, 3 I I :247-257.

30. Frymoyer JW, Pope MH: Fracture healing in the sciatically denervated rat. J Trauma 1977, I7:355-36I. 
31. Aro H, Eerola E, Aho AJ, Penttinen R: Healing of experimental fractures in the denervated limbs of the rat. Clin Orthop 1981, I 55:21 I-2I7.

32. Aro $\mathrm{H}$ : Effect of nerve injury on fracture healing. Callus formation studied in the rat. Acta Orthop Scand 1985, 56:233-237.

33. Nordsletten L, Madsen JE, Almaas R, Rootwelt T, Halse J, Konttinen YT, Hukkanen M, Santavirta S: The neuronal regulation of fracture healing. Effects of sciatic nerve resection in rat tibia. Acta Orthop Scand 1994, 65:299-304.

34. Grills BL, Schuijers JA, Ward AR: Topical application of nerve growth factor improves fracture healing in rats. J Orthop Res 1997, 1 5:235-242

35. Meyer RA, Meyer MH: The effect of age on the expression of mitochondrial genes during the healing of femoral fractures in the rat. J Bone Miner Res 2003, I 8:S258 (Abstract).

36. Etienne W, Meyer MH, Peppers J, Meyer RA Jr: Comparison of mRNA gene expression by RT-PCR and DNA microarray. BioTechniques 2004, 36:618-626.

37. Meyer $M H$, Etienne $W$, Meyer RA: The effect of age on the expression of nerve-related genes during the healing of femoral fractures in the rat. J Bone Miner Res 2003, I 8:S258 (Abstract).

38. Diaz-Horta O, Kamagate A, Herchuelz A, Van Eylen F: $\mathbf{N a} / \mathbf{C a}$ exchanger overexpression induces endoplasmic reticulumrelated apoptosis and caspase- 12 activation in insulin-releasing BRIN-BDI I cells. Diabetes 2002, 5 I: |8|5-|824.

39. Feldkamp MM, Gutmann DH, Guha A: Neurofibromatosis type I: Piecing the puzzle together. Can J Neurol Sci 1998, 25:|8|-|9|.

40. Signs SA, Jacquet R: Induction of ethanol dependence increases signal peptidase mRNA levels in rat brain. Mol Cell Biochem 1994, I 39:21-26.

4I. Su Y, Ganea D, Peng X, Jonakait GM: Galanin down-regulates microglial tumor necrosis factor-alpha production by a posttranscriptional mechanism. I Neuroimmunol 2003, 134:52-60.

42. Wynick D, Thompson SW, McMahon SB: The role of galanin as a multi-functional neuropeptide in the nervous system. Curr Opin Pharmacol 2001, I:73-77.

43. Bacon A, Holmes FE, Small C], Ghatei M, Mahoney S, Bloom S, Wynick D: Transgenic over-expression of galanin in injured primary sensory neurons. Neuroreport 2002, I 3:2। 29-2132.

44. Uwabe K, Gahara Y, Yamada H, Miyake T, Kitamura T: Identification and characterization of a novel gene (neurorep I) expressed in nerve cells and up-regulated after axotomy. Neuroscience 1997, 80:501-509.

45. Zaheer A, Lim R: In vitro inhibition of MAP kinase (ERKI/ ERK2) activity by phosphorylated glia maturation factor (GMF). Biochemistry 1996, 35:6283-6288

46. Bourgeois F, Guimiot F, Mas C, Bulfone A, Levacher B, Moalic JM Simonneau $M$ : Identification and isolation of a full-length clone of mouse GMFB (Gmfb), a putative intracellular kinase regulator, differentially expressed in telencephalon. Cytogenet Cell Genet 2001, 92:304-309.

47. Kaplan R, Zaheer A, Jaye M, Lim R: Molecular cloning and expression of biologically active human glia maturation factor-beta. J Neurochem 1991, 57:483-490.

48. Carter RE, Cerosaletti KM, Burkin DJ, Fournier RE, Jones C, Greenberg BD, Citron BA, Festoff BW: The gene for the serpin thrombin inhibitor (PI7), protease nexin $I$, is located on human chromosome 2 q33-q35 and on syntenic regions in the mouse and sheep genomes. Genomics 1995, 27:196-199.

49. Crisp RJ, Knauer MF, Knauer DJ: Protease nexin I is a potent urinary plasminogen activator inhibitor in the presence of collagen type IV.J Biol Chem 2002, 277:47285-4729I.

50. Moore C, Perry AC, Love S, Hall L: Sequence analysis and immunolocalisation of phosphatidylethanolamine binding protein (PBP) in human brain tissue. Brain Res Mol Brain Res 1996, 37:74-78.

51. Itoh A, Miyabayashi T, Ohno M, Sakano S: Cloning and expressions of three mammalian homologues of Drosophila slit suggest possible roles for Slit in the formation and maintenance of the nervous system. Brain Res Mol Brain Res 1998, 62: I75-186.

52. Chung RS, Vickers JC, Chuah MI, Eckhardt BL, West AK: Metallothionein-III inhibits initial neurite formation in developing neurons as well as postinjury, regenerative neurite sprouting. Exp Neurol 2002, I 78: |-I2.
53. Palmiter RD, Findley SD, Whitmore TE, Durnam DM: MT-III, a brain-specific member of the metallothionein gene family. Proc Natl Acad Sci USA 1992, 89:6333-6337.

54. Tran NL, Adams DG, Vaillancourt RR, Heimark RL: Signal transduction from $\mathbf{N}$-cadherin increases $\mathrm{Bcl}-2$. Regulation of the phosphatidylinositol 3-kinase/Akt pathway by homophilic adhesion and actin cytoskeletal organization. J Biol Chem 2002, 277:32905-329|4.

55. Rhee J, Mahfooz NS, Arregui C, Lilien J, Balsamo J, VanBerkum MF: Activation of the repulsive receptor Roundabout inhibits $\mathbf{N}$. cadherin-mediated cell adhesion. Nat Cell Biol 2002, 4:798-805.

56. Janssen-Timmen $U$, Lemaire $P$, Mattei MG, Revelant $O$, Charnay $P$. Structure, chromosome mapping and regulation of the mouse zincfinger gene Krox-24; evidence for a common regulatory pathway for immediate early serum-response genes. Gene 1989, 80:325-336

57. Sukhatme VP, Cao X, Chang LC, Tsai-Morris CH, Stamenkovich D, Ferreira PCP, Cohen DR, Edwards SA, Shows TB, Curran T, Le Beau $M M$, Adamson ED: $A$ zinc finger-encoding gene coregulated with c-fos during growth and differentiation, and after cellular depolarization. Cell 1988, 53:37-43.

58. Tare RS, Oreffo RO, Sato K, Rauvala H, Clarke NM, Roach HI: Effects of targeted overexpression of pleiotrophin on postnatal bone development. Biochem Biophys Res Commun 2002 , 298:324-332.

59. Kretschmer PJ, Fairhurst JL, Decker MM, Chan CP, Gluzman Y, Bohlen P, Kovesdi I: Cloning, characterization and developmental regulation of two members of a novel human gene family of neurite outgrowth-promoting proteins. Growth Factors 1991, 5:99-I14.

60. Pavlov I, Voikar V, Kaksonen M, Lauri SE, Hienola A, Taira T, Rauvala $\mathrm{H}$ : Role of heparin-binding growth-associated molecule (HBGAM) in hippocampal LTP and spatial learning revealed by studies on overexpressing and knockout mice. Mol Cell Neurosci 2002, 20:330-342.

61. Walton KM, Martell KJ, Kwak SP, Dixon JE, Largent BL: A novel receptor-type protein tyrosine phosphatase is expressed during neurogenesis in the olfactory neuroepithelium. Neuron 1993, I I :387-400.

62. La Bella V, Cisterni C, Salaun D, Pettmann B: Survival motor neuron (SMN) protein in rat is expressed as different molecular forms and is developmentally regulated. Eur J Neurosci 1998 , 10:2913-2923.

63. Bloom L, Horvitz HR: The Caenorhabditis elegans gene unc-76 and its human homologs define a new gene family involved in axonal outgrowth and fasciculation. Proc Natl Acad Sci USA 1997, 94:3414-3419.

64. Manser E, Fernandez D, Loo L, Goh PY, Monfries C, Hall C, Lim L: Human carboxypeptidase $E$. Isolation and characterization of the cDNA, sequence conservation, expression and processing in vitro. Biochem / 1990, 267:517-525.

65. Cool DR, Normant E, Shen F, Chen HC, Pannell L, Zhang Y, Loh YP: Carboxypeptidase $E$ is a regulated secretory pathway sorting receptor: Genetic obliteration leads to endocrine disorders in Cpe(fat) mice. Cell 1997, 88:73-83.

66. Danielson PE, Forss-Petter S, Battenberg EL, deLecea L, Bloom FE Sutcliffe JG: Four structurally distinct neuron-specific olfactomedin-related glycoproteins produced by differential promoter utilization and alternative mRNA splicing from a single gene. J Neurosci Res 1994, 38:468-478.

67. Takeuchi M, Hata Y, Hirao K, Toyoda A, Irie M, Takai Y: SAPAPs. A family of PSD-95/SAP90-associated proteins localized at postsynaptic density. J Biol Chem 1997, 272: I I943- I I95 I.

68. Elferink LA, Anzai K, Scheller RH: rab I5, a novel low molecular weight GTP-binding protein specifically expressed in rat brain. J Biol Chem 1992, 267:5768-5775.

69. Lai C, Lemke G: Structure and expression of the Tyro 10 receptor tyrosine kinase. Oncogene 1994, 9:877-883.

70. Chen Q, Pearlman RE, Moens PB: Isolation and characterization of a cDNA encoding a synaptonemal complex protein. Biochem Cell Biol 1992, 70:1030-1038.

7I. McPherson PS, Garcia EP, Slepnev VI, David C, Zhang X, Grabs D Sossin WS, Bauerfeind R, Nemoto Y, De Camilli P: A presynaptic inositol-5-phosphatase. Nature 1996, 379:353-357. 
72. Smith KE, Borden LA, Wang CH, Hartig PR, Branchek TA, Weinshank $\mathrm{RL}$ : Cloning and expression of a high affinity taurine transporter from rat brain. Mol Pharmacol 1992, 42:563-569.

73. Pevsner J, Hsu SC, Hyde PS, Scheller RH: Mammalian homologues of yeast vacuolar protein sorting (vps) genes implicated in Golgi-to-lysosome trafficking. Gene 1996, I 83:7-14.

74. Furley AJ, Morton SB, Manalo D, Karagogeos D, Dodd J, Jessell TM: The axonal glycoprotein TAG-I is an immunoglobulin superfamily member with neurite outgrowth-promoting activity. Cell 1990, 6I:157-170.

75. Tsui CC, Copeland NG, Gilbert DJ, Jenkins NA, Barnes C, Worley PF: Narp, a novel member of the pentraxin family, promotes neurite outgrowth and is dynamically regulated by neuronal activity. J Neurosci 1996, 16:2463-2478.

76. Senner V, Kismann E, Puttmann S, Hoess N, Baur I, Paulus W: LI expressed by glioma cells promotes adhesion but not migration. Glia 2002, 38: |46-|54.

77. Hlavin ML, Lemmon V: Molecular structure and functional testing of human LICAM: An interspecies comparison. Genomics 1991, I 1:416-423.

78. Kamiguchi H, Lemmon V: A neuronal form of the cell adhesion molecule LI contains a tyrosine-based signal required for sorting to the axonal growth cone. I Neurosci 1998 I 8:3749-3756.

79. Bianchi MT, MacDonald RL: Slow phases of GABA(A) receptor desensitization: Structural determinants and possible relevance for synaptic function. J Physiol 2002, 544:3-18.

80. el Mestikawy S, Giros B, Pohl M, Hamon M, Kingsmore SF, Seldin MF, Caron MG: Characterization of an atypical member of the $\mathrm{Na}+/ \mathrm{Cl}(-)$-dependent transporter family: Chromosomal localization and distribution in GABAergic and glutamatergic neurons in the rat brain. J Neurochem 1994, 62:445-455.

81. Smith KE, Fried SG, Durkin MM, Gustafson EL, Borden LA, Branchek TA, Weinshank RL: Molecular cloning of an orphan transporter. A new member of the neurotransmitter transporter family. FEBS Lett 1995, 357:86-92.

82. Stenius K, Janz R, Sudhof TC, Jahn R: Structure of synaptogyrin (p29) defines novel synaptic vesicle protein. J Cell Biol 1995, |31:1801-1809.

83. Li C, Ullrich B, Zhang JZ, Anderson RG, Brose N, Sudhof TC: $\mathrm{Ca}(2+)$-dependent and -independent activities of neural and non-neural synaptotagmins. Nature 1995, 375:594-599.

84. Ribeiro CS, Carneiro K, Ross CA, Menezes JR, Engelender S: Synphilin-I is developmentally localized to synaptic terminals, and its association with synaptic vesicles is modulated by alphasynuclein. J Biol Chem 2002, 277:23927-23933.

85. Kim J, Jones BW, Zock C, Chen Z, Wang H, Goodman CS, Anderson $D$ ): Isolation and characterization of mammalian homologs of the Drosophila gene glial cells missing. Proc Natl Acad Sci USA 1998, 95:12364-12369.

86. Oppenheim RW, Houenou LJ, Johnson JE, Lin LF, Li L, Lo AC, Newsome AL, Prevette DM, Wang S: Developing motor neurons rescued from programmed and axotomy induced cell death by GDNF. Nature 1995, 373:344-346.

87. Sangameswaran L, Hempstead J, Morgan Jl: Molecular cloning of a neuron-specific transcript and its regulation during normal and aberrant cerebellar development. Proc Natl Acad Sci USA 1989, 86:565|-5655.

88. Kawasaki M, Uchida S, Monkawa T, Miyawaki A, Mikoshiba K, Marumo F, Sasaki S: Cloning and expression of a protein kinase C-regulated chloride channel abundantly expressed in rat brain neuronal cells. Neuron 1994, 12:597-604.

89. Wu J, Li J, Huang KP, Huang FL: Attenuation of protein kinase C and CAMP-dependent protein kinase signal transduction in the neurogranin knockout mouse. J Biol Chem 2002, 277:19498-19505

90. Welch SK, O'Hara BF, Kilduff TS, Heller HC: Sequence and tissue distribution of a candidate G-coupled receptor cloned from rat hypothalamus. Biochem Biophys Res Commun 1995 209:606-6I3.

91. Martin SC, Russek SJ, Farb DH: Molecular identification of the human GABABR2: Cell surface expression and coupling to adenylyl cyclase in the absence of GABABRI. Mol Cell Neurosci 1999, 13:180-191.
92. Dou D, Joseph R: Cloning of human neuronatin gene and its localization to chromosome $20 \mathrm{qI}$ I.2-I2: The deduced protein is a novel "proteolipid". Brain Res 1996, 723:8-22.

93. Pedrazzini T, Seydoux J, Kunstner P, Aubert JF, Grouzmann E, Beermann F, Brunner HR: Cardiovascular response, feeding behavior and locomotor activity in mice lacking the NPY Y I receptor. Nat Med 1998, 4:722-726.

94. Kitlinska J, Lee EW, Movafagh S, Pons J, Zukowska Z: Neuropeptide Y-induced angiogenesis in aging. Peptides 2002, 23:7I-77.

95. Fujino T, Yamamoto T: Cloning and functional expression of a novel long-chain acyl-CoA synthetase expressed in brain. Biochem (Tokyo) 1992, II I:197-203.

96. Dickson BJ: Molecular mechanisms of axon guidance. Science 2002, 298: 1959-1964.

97. Noel LS, Champion BR, Holley CL, Simmons CJ, Morris DC, Payne JA Lean JM, Chambers TJ, Zaman G, Lanyon LE, Suva LJ, Miller LR: RoBo-I, a novel member of the urokinase plasminogen activator receptor/CD59/Ly-6/snake toxin family selectively expressed in rat bone and growth plate cartilage. $J$ Biol Chem 1998, 273:3878-3883.

98. Alimova-Kost MV, Ninkina NN, Imreh S, Gnuchev NV, Adu J, Davies AM, Buchman VL: Genomic structure and chromosomal localization of the mouse persyn gene. Genomics 1999, 56:224-227.

99. Pan ZZ, Bruening W, Giasson BI, Lee VM, Godwin AK: Gammasynuclein promotes cancer cell survival and inhibits stressand chemotherapy drug-induced apoptosis by modulating MAPK pathways. J Biol Chem 2002, 277:35050-35060.

100. Petropoulos I, Part D, Ochoa A, Zakin MM, Lamas E: NOR-2 (neuron-derived orphan receptor), a brain zinc finger protein, is highly induced during liver regeneration. FEBS Lett 1995, 372:273-278.

I0I. Hirose T, Tamaru T, Okumura N, Nagai K, Okada M: PCTAIRE 2, a Cdc2-related serine/threonine kinase, is predominantly expressed in terminally differentiated neurons. Eur / Biochem 1997, 249:48|-488.

102. Okuda T, Cleveland JL, Downing JR: PCTAIRE-I and PCTAIRE3 , two members of a novel cdc2/CDC28-related protein kinase gene family. Oncogene 1992, 7:2249-2258.

103. Milev P, Friedlander DR, Sakurai T, Karthikeyan L, Flad M, Margolis RK, Grumet M, Margolis RU: Interactions of the chondroitin sulfate proteoglycan phosphacan, the extracellular domain of a receptor-type protein tyrosine phosphatase, with neurons, glia, and neural cell adhesion molecules. J Cell Biol 1994, I27: $1703-1715$

104. Waldmann R, Bassilana F, de Weille J, Champigny G, Heurteaux C Lazdunski M: Molecular cloning of a non-inactivating protongated $\mathrm{Na}+$ channel specific for sensory neurons. J Biol Chem 1997, 272:20975-20978.

105. Hirao K, Hata Y, Ide N, Takeuchi M, Irie M, Yao I, Deguchi M, Toyoda A, Sudhof TC, Takai Y: A novel multiple PDZ domain-containing molecule interacting with $\mathbf{N}$-methyl-D-aspartate receptors and neuronal cell adhesion proteins. J Biol Chem 1998 , 273:21105-21110.

106. Shoji H, Tsuchida K, Kishi H, Yamakawa N, Matsuzaki T, Liu Z, Nakamura $T$, Sugino $H$ : Identification and characterization of a PDZ protein that interacts with activin type II receptors. J Biol Chem 2000, 275:5485-5492.

107. Uhl GR, Kitayama S, Gregor P, Nanthakumar E, Persico A, Shimada S: Neurotransmitter transporter family cDNAs in a rat midbrain library: 'orphan transporters' suggest sizable structural variations. Brain Res Mol Brain Res 1992, I 6:353-359.

108. Witzemann V, Stein E, Barg B, Konno T, Koenen M, Kues W, Criado $M$, Hofmann M, Sakmann B: Primary structure and functional expression of the alpha-, beta-, gamma-, delta- and epsilonsubunits of the acetylcholine receptor from rat muscle. Eur J Biochem 1990, 194:437-448.

109. Lund LM, McQuarrie IG: Calcium/calmodulin-dependent protein kinase Ilbeta isoform is expressed in motor neurons during axon outgrowth and is part of slow axonal transport. Neurosci Res 2002, 67:720-728.

1 10. Klar A, Baldassare M, Jessell TM: F-spondin: A gene expressed at high levels in the floor plate encodes a secreted protein that promotes neural cell adhesion and neurite extension. Cell 1992, 69:95-I I0.

III. Friedlander DR, Milev P, Karthikeyan L, Margolis RK, Margolis RU, Grumet $M$ : The neuronal chondroitin sulfate proteoglycan 
neurocan binds to the neural cell adhesion molecules $\mathbf{N g}$ CAM/LI/NILE and N-CAM, and inhibits neuronal adhesion and neurite outgrowth. J Cell Biol 1994, I 25:669-680.

1 12. Qi ML, Wakabayashi Y, Enomoto M, Shinomiya K: Changes in neurocan expression in the distal spinal cord stump following complete cord transection: A comparison between infant and adult rats. Neurosci Res 2003, 45:18I-I88.

1 13. Chen S, Gil O, Ren YQ, Zanazzi G, Salzer JL, Hillman DE: Neurotrimin expression during cerebellar development suggests roles in axon fasciculation and synaptogenesis. J Neurocytol 200I, 30:927-937.

114. Rowen L, Young J, Birditt B, Kaur A, Madan A, Philipps DL, Qin S, Minx P, Wilson RK, Hood L, Graveley BR: Analysis of the human neurexin genes: Alternative splicing and the generation of protein diversity. Genomics 2002, 79:587-597.

115. Arber S, Caroni P: Thrombospondin-4, an extracellular matrix protein expressed in the developing and adult nervous system promotes neurite outgrowth. J Cell Biol 1995, | 3 1:1083-1094.

116. Tucker RP, Adams JC, Lawler J: Thrombospondin-4 is expressed by early osteogenic tissues in the chick embryo. Dev Dyn 1995, 203:477-490.

117. Lawler J, McHenry K, Duquette M, Derick L: Characterization of human thrombospondin-4. J Biol Chem 1995, 270:2809-28I4.

1 18. Burgess HA, Reiner O: Cleavage of doublecortin-like kinase by calpain releases an active kinase fragment from a microtubule anchorage domain. J Biol Chem 200I, 276:36397-36403.

I19. Sakai H, Nakashima S, Yoshimura S, Nishimura Y, Sakai N, Nozawa Y: Molecular cloning of a cDNA encoding a serine protease homologous to complement CIs precursor from rat C6 glial cells and its expression during glial differentiation. Gene 1998 , 209:87-94.

\section{Pre-publication history}

The pre-publication history for this paper can be accessed here:

http://www.biomedcentral.com/1471-2474/5/24/prepub
Publish with Bio Med Central and every scientist can read your work free of charge

"BioMed Central will be the most significant development for disseminating the results of biomedical research in our lifetime. "

Sir Paul Nurse, Cancer Research UK

Your research papers will be:

- available free of charge to the entire biomedical community

- peer reviewed and published immediately upon acceptance

- cited in PubMed and archived on PubMed Central

- yours - you keep the copyright

Submit your manuscript here:

http://www.biomedcentral.com/info/publishing_adv.asp
Biomedcentral 